\title{
The distribution of nationalist and racist discourse
}

\section{Gavan Titley}

To cite this article: Gavan Titley (2020) The distribution of nationalist and racist discourse, Journal of Multicultural Discourses, 15:3, 257-266, DOI: 10.1080/17447143.2020.1780245

To link to this article: https://doi.org/10.1080/17447143.2020.1780245

曲 Published online: 22 Jun 2020.

Submit your article to this journal $₫$

Џll Article views: 251

Q View related articles $ᄃ$

View Crossmark data ¿`

Citing articles: 1 View citing articles ๔ 


\section{The distribution of nationalist and racist discourse}

\section{Gavan Titley}

Department of Media Studies, Maynooth University, Maynooth, Ireland

Bart Cammaert's galvanising analysis of what he terms 'neo-fascist discourse' sets out a framework for understanding the reproduction of what appear to be strikingly congruent modes of nationalist articulation across otherwise disparate political contexts. His argument is bracingly normative and political, calling for a defence of democratic public cultures against the 'recent worldwide rise of neo-fascism'. His two contexts of analysis underline the political and analytical challenge posed by this conjunctural pattern of divergence and convergence, a complexity too often veiled in narratives of contemporary authoritarian nationalist ascendance. Centre stage, inevitably, is the opportunistic and careering nativism of Donald Trump in the United States, who, from his campaign onwards, recognised the political value of overtly staging the racism of American imperialism, of rendering discursive those forms of violence that have habitually proceeded through elision and euphemism. His scattergun scapegoating, in this late phase of his presidency, seems increasingly machine-generated from a word cloud of his tweets. The implacably material and social demands of the Covid-19 pandemic have, despite the political labour invested in racialising the disease, proven difficult to navigate for a range of authoritarian and 'populist' actors (Gerbaudo 2020). For Trump, enemies and conspiracies have consequently proliferated. Fake scientists, and fake science, coming between a president and his people - even as Trump calculates, in plain sight, just how many of these people can be relegated to what Achille Mbembe, in Critique of Black Reason, terms the 'superfluous humanity' increasingly extraneous to the needs of capital $(2017,3)$.

The Trumpian spectacle is paired with the hegemony of right-wing Hindu nationalism in India under Narendra Modi and the highly organised Bharatiya Janata Party (BJP). Against the backdrop of a significant economic downturn, the 2019 elections saw the BJP increase its seats and vote share in the lower house, campaigning on a platform of deflecting debate on the economy through a defence of the ' ... unity and national security supposedly threatened from without by Pakistan and Muslim migrations from neighbouring states, and from within by Muslim (and secularist) hostility to, and distance from, the culturally Hindu foundations of Indian nationalism' (Vanaik 2019). In August, Modi annulled Article 370 of the constitution, revoking the autonomous status of Jammu and Kashmir, and instigating a brutal lockdown and blackout. By year's end, the government has pushed through the Citizenship Amendment Act, which explicitly differentiated between the claims of Muslim and non-Muslim minorities to naturalisation. Widely regarded as a prelude to a national register of citizens which would significantly enhance systemic anti-Muslim discrimination (Vanaik 2019, the passage of the act was

CONTACT Gavan Titley gavan.titley@helsinki.fi 
met with widespread protest from diverse coalitions, in turn greeted by police repression and violence from Saffron goon squads. Here, the pandemic spread through a fractious and unsettled political juncture, and, faced with the extraordinary human tragedy of millions of day labourers stranded during the lockdown, significant political and media labour has, predictably, been invested in blaming Muslims for deliberately spreading the virus (Yasir 2020).

The 'Chinese virus' and 'corona jihad' - the organic universalism of Covid-19 has been recouped to the delineation of enemies within and without, organised around and through what Cammaerts proposes as the 'core nodal points of neo-fascist discourse'. Leaving aside, momentarily, the debates this reference to fascism inevitably indexes, any invocation of fascism recognises how it seeks to privilege the - ethnic, racialised nation above all else. In this relation, his four points of orientation fall into two categories. The first two speak to what Arjun Appadurai (2006) describes as the 'inherent ethnicist tendency in all ideologies of nationalism', a tendency which, under conditions of politicaleconomic uncertainty or social flux, dynamically combines a conviction of 'ethnic genius' (hence the attempted naturalisation of 'hierarchy, inequality and superiority') with righteous anger as to its misrecognition, dilution or betrayal (thus the cultivated and notably gendered resentments of 'ultra-nationalism, religion and nativism'). Taken together, these two nodes capture desires to fix and reduce the legitimate public of irreducibly multicultural societies. This occurs through a double movement astutely captured by Sivamohan Valluvan, who argues that understanding the 'compositional specificity of nationalism' requires grasping how

... the exclusionary principle that the nation hinges on not only 'inferiorises' those who are defined as not belonging but also renders the excluded Other the overdetermined and outsized object of political discourse - determining in turn the character and content of putatively democratic deliberation writ large ... To be at the sharp end of a nationalist politics is to know yourself not only as an outsider, but also as an outsider who is actively and incessantly spoken of'. (2019, 35-36)

Underpinning Cammaert's attention to discourse is a keen sense that this incessant speech about them has, across multiple contexts, become more politically viable, and more excitable and less inhibited in this nationalist juncture. The exemplary material he presents is unwilling to disguise the affective pleasures of racist or misogynist transgression, revelling instead in the performative truth value produced by refusing to be cowed by the imagined repression of political correctness, or 'multicultural orthodoxy'. It is uninterested in the public fictions of minimal ideological coherence when relentless projection and semiotic opportunism will do just fine. What matters is the structure of feeling and a return on its affective dividends. Both Valluvan and Cammaert's analysis underlines the need to take this kind of discourse seriously, even in a context of endless discursive noise, as a form of cumulative action. To be spoken of and positioned in these relations is to be acted on, and rendered vulnerable to further action. Take two of Europe's most authoritarian nationalist governments, in Hungary and Poland, both reprimanded of late by the European Union for 'undermining the rule of law'. Their political priorities during the pandemic have involved revoking legal gender recognition (Hungary) and attempting to further tighten already punitive abortion legislation (Poland), set pieces aimed at buffering a 'culture war' predicated on resolutely confronting the imported threat of 
'the gender ideology' to the families of the nation, that is, to the nation as a family (on this relation see Lapierre 2020). In this structure of feeling, the nation is always under siege, and thus the intensity of the discourse that Cammaerts analyses can be justified as nothing more than the unvarnished expression of ordinary and legitimate fears. His attention to processes of (attempted) normalisation, in this regard, is critically important.

Cammaert's second pair of nodes ('anti-intellectualism, lies and conspiracy theories', and 'anti-enlightenment and anti-democratic values') turn to the conditions of political discourse, linking the integralist refusal of 'the public' with a refusal of the values and procedures of public culture. The analysis, for pragmatic or didactic reasons, brackets a considerable set of issues to foreground a normative vision primarily traduced by neofascist will to power. It is worth noting, nonetheless, that tracing productive connections to other structural factors and political dynamics does not particularly weaken the force of the argument.

In relation to the latter node, the often open hostility of - democratically elected nationalists and authoritarians to democratic values, and to the procedures, institutions and processes of representative democracies, has to be understood as articulated and given force within a more encompassing, multi-faceted 'crisis of democracy', or more pointedly, the crisis of democracy's relation to capitalism. One must be very careful in making this analytical move, for the reductionist conviction that authoritarian nationalism is a direct response to the depredations of globalised capitalism - and thus an unmediated if wayward expression of working class injury - is increasingly parlayed into calls for, when all is said and done, a more nationalist and anti-immigration left primed to capture and convert what is held to be an 'anti-capitalist energy coursing through vernacular nationalist politics' (Valluvan 2019, 169). This seam of misrecognition is politically disastrous, missing, inter alia, how the clamorous resentment mobilised by the radical right, in the aftermath of the global economic crisis and neoliberalism's crash and state-enforced resurrection, is articulated through what Wendy Brown terms 'novel articulations and expressions of freedom' $(2018,61)$.

The drive of neoliberalism, she argues, has been to cast the agonism of politics as an arbitrary restriction, and the social as an anti-individualist fiction, with the effect of undermining 'norms and practices of inclusion, pluralism, tolerance and equality across the board'. The nationalisms that promise renewal in societies fractured by 'eroded socioeconomic status and new forms of insecurity' can inveigh against globalisation, but can do little more than exact revenge on 'globalism' - taking back control from 'immigrants', racialised minorities, 'cosmopolitan diversity' - by attempting to ' ... realign the figure and voice of the nation with the figure and voice of nativism' $(2018,69)$. Freedom, therefore, has emerged as a signature theme of 'manifestly unemancipatory' forms of authoritarianism and nationalist backlash, where the desire to suppress any reflexive recognition of the demands of 'inclusion, tolerance and equality' can be encoded as liberty from capricious and repressive restraint. Witness the flourishing of what Nicholas Mirzoeff (2020) noted as 'visual media fascism', such as eugenicist and supremacist memes and symbolism, during 'anti-lockdown' protests in the United States: freedom from Big Government, but also freedom from the virus as a social relation, and the web of unimaginable equivalences and unthinkable obligations this conjures up. Cammaert's emphasis on the insistent fascist appropriation of 'freedom of speech' - a strategic move with a far longer history than the staged campus controversies of the last years (see Smith 2020) - further illustrates 
freedom's mutable valence. What is at stake in so many free speech conflicts involving the radical right is not the classic defence of negative liberty, but freedom from criticism and opposition, freedom to say anything, in any venue, in any way desired, without consequence, without restraint (Titley 2020).

Revealing the mechanics of value appropriation, nonetheless, does little to substantively recuperate 'the Enlightenment' as the lodestar of democratic public culture. It is not just because, as Cammaerts recognises, hailing the 'ideas and values' associated with theoften stylised and Eurocentric periodisation of Enlightenment requires working through its well-documented entanglements with the modern formation of race (Mills 1997). It is also because the contemporary radical right does not only 'selectively cherry-pick from democratic and enlightenment values', but channels and amplifies a repressive potential generated by the importance of values discourse to the border and integration governmentality of the post $9 / 11$ period. This can be teased out by way of an example that also illustrates the communicative dynamics critical to the article's analysis.

As I was drafting this commentary, a minor Twitter storm was playing itself out. Three UK Conservative Party MPs, one of them a Minister, had retweeted a video from a now defunct far-right account purporting to show the recently elected leader of the British Labour Party, Keir Starmer, 'explaining why he didn't prosecute grooming gangs when we was head of the Crown Prosecution Service'. The video, a television interview recorded in 2013, had been doctored from Starmer explaining that he had, in fact, changed prosecution guidelines to an apparent set of excuses for a lack of any such changes.

This manipulated digital artefact, and its ease of circulation, perfectly encapsulates the intersection of 'lying as tactic' and informational conditions that Cammaerts focuses on. Or, put another way, there is the very little political possibility to recall this action to the status of a 'lie', or deliberate deception - the politicians all eventually deleted their tweets, but without any admission of wrongdoing. In Infoglut (2013), Mark Andrejevic provides one of the most compelling accounts of the mesh of political conditions and informational dynamics often, and unhelpfully, approached as a condition of 'post-truth'. Conditions of informational abundance, where information is circulated and pooled at speed across dense networks of platform media, serve to multiply evidence, data and versions of reality to an extent that not only renders all accounts potentially relative to each other, but which galvanises a ' ... recognition of the constructed and partial nature of representation' $(2013,3)$. These conditions of fragmentation and proliferation disrupt the fewto-many communicative relation associated with power over meanings, perceptions and attitudes, instead facilitating the disruptive power of narrative multiplication, the proliferation of multiple competing versions and the weaponisation of reasonable doubt. What matters, in the logic of circulation, is not so much whether the video turns out to be true (or false), as any reckoning with its status is anyway diluted in the accelerated circuitries of the 'attention economy'. Instead, it is the labour relation it instigates; a retweet takes an instant whereas a denial requires dedicated work.

The video is presented as Starmer unwittingly revealing a 'cover-up', a generic claim that chimes with the hyper-suspicion of the designs of elite power common to contemporary conspiracy theories. It also has a more established genealogy in the 'anti anti-racism' of the Conservative New Right in Britain. From the 1980s onwards its partisans sought to present themselves as the valiant resistance to a hegemonic 'multiculturalism', which 
not only acted to undermine national identity, but set out to do so by stealth, ignoring and suppressing all evidence of the corrosive impact of 'immigrants' on culture and society (Burnett 2015). The precise background to the video is important to this point, and can be traced back to 2010, when five men were jailed in Rotherham, South Yorkshire, for sex offences committed against children. Framed in tabloid media as a problem of 'Asian grooming gangs', the case made periodic returns to the spotlight, particularly in 2012 when an investigation by The Times alleged that the child abuse had taken place on a much wider scale, but that there had been a reluctance to investigate 'Asian suspects' for fear of enflaming community relations and upsetting 'multicultural sensibilities'. In an analysis of the media coverage of the issue over these years, Waqas Tufail is scathing as to the prevalence and consequence of a 'conjured image' of the ' ... dark Muslim male, sexually charged, violent, refusing to integrate and serving as an embodiment of a backward religion and dangerous, inferior culture. This (mis)representation has had serious consequences for Muslim communities which have experienced isolation, alienation, racist attacks and criminalisation as a result' $(2015,39)$.

One such consequence was to continually attract the far right to Rotherham to stage protests and media specatacles, and the diversity of fascistic movements that descended there over this period is instructive. In European political analysis, the 'far-right' category is often used to encompass parties and movements invested in varying intensities of racialised nativism and nationalism, while differentiating between an 'extreme' right hostile to representative democracy and often compromised of neo-Nazi and fascist groupuscules, and a 'radical' right that is electorally active while hostile to what it sees as the liberal democratic order). In histories of post-war Europe, this had led a prevalent focus on the development of 'party waves';

The first, between 1945 and 1955, was characterized by its proximity to the totalitarian ideologies of the 1930s; it is often called 'neo-Fascist'. The second wave, which arose in the mid1950s, corresponded to the movement of the radicalized middle classes. Their 'third wave', which a number of authors have called 'nationalist populist', arrived between the 1980s and 2001. And since September 11, 2001, the fourth wave has unfurled, a populist expression of the 'clash of civilizations'. (Camus and Lebourg 2017, 44)

In Rotherham, several of these waves washed up simultaneously. The British National Party (BNP), which emerged from the violent, fascistic National Front during the 1980s, always struggled to box off its national socialist orientation even as its 'suited and booted' incarnation gained unprecedented electoral success in the late 2000s. It imploded internally in 2010 , and by the time it sought to involve itself in protests in Rotherham - handing out leaflets claiming, like the retweeted video, that '..young girls gang raped in Rotherham by Pakistanis while Labour cover it up' (Kelsey 2017, 110) - it was a spent force. On the other hand, the English Defence League (EDL) - which in 2014 established a protest camp outside the town's police station, calling for the resignation of South Yorkshire's Police Commissioner - more successfully fused English nativism with the discursive repertoire of 'fourth wave' transnational, anti-Muslim racism; 'Rape jihad, that's what it is when Muslim men abuse the next generation of English mothers' (Kelsey 2017). As the EDL in turn splintered, the baton was taken up by Britain First, a party that fused EDL civilizationism with a renewal of the BNP's anti-immigration racism and a dose of evangelical rapture. ${ }^{1}$ While Britain First staged media-oriented protests outside mosques, for 
example, its main claim to fame was its status as Britain's largest political party on Facebook (a Buzzfeed study demonstrated how a clever posting and post-boosting strategy brought its posts to millions of users, see Ball 2017). A study by Tell MAMA demonstrated how the party used a continual stream of posts about the Rotherham 'cover up' to circulate an extraordinary level of openly racist material (2014).

Like so many other nominally centrist politicians, the Tory retweeters connected themselves to this fast-changing digital-political far-right milieu, seduced, in a generous reading, by the account's practiced appeal to democratic accountability and human rights. However, I think it is important to underline here that it is not possible to understand this 'cherrypicking' without paying attention to the repressive, disciplinary work 'liberal and enlightenment values' that were sutured to in the post 9/11 period. The invasions of Afghanistan and Iraq, as Tony Blair declared, were 'not just about changing regimes but changing the value systems governing the nations involved' (quoted in Kundnani 2014, loc. 1099). And as these invasions were prosecuted in the key of freedom, Muslim and Muslim-looking populations in the imperial metropoles were subjected to intensive securitisation, and the ratcheting up of a border politics of 'integration' that linked national security to social cohesion, and social cohesion to the values orientation of 'Muslim communities'. As Markha Valenta notes, 'To be interpellated by the state as "Muslim" makes one subject to the treatment meted out to "Muslims", locking into place these citizen's public-political subjectivity regardless of the subject's own identification' $(2017,133)$. Despite rote political recognition of the ethnic, cultural, ideological and social diversity of Muslim populations, the politics of securitisation and integration produces a performative 'Muslim culture' not only as a product of surveillance, but also as a site where 'moderate' Muslims must continually be seen to dissociate themselves from 'dangerous beliefs and identities' by pledging allegiance to liberal values.

The liberal integrationism of this period actively dissociated itself from the singular national ethnos of 'problematic' forms of nationalism, positing liberal values instead as defining of a shared national modus vivendi. It just so happens that these values, with gender equality and sexual freedom to the foreground, are established dimensions of a hegemonic national culture, contrasted with the 'parallel societies' of patriarchal, homophobic and dangerously illiberal non-white, non-western others. It is important to understand this as a form of governmentality that was particularised in divergent ways in different countries. As Jan Dobbernak argued in relation to the 'muscular liberalism of British values' articulated by David Cameron in 2011, such political projects were not 'stimulus-response models' with 'coherent and continuous orientation' but rather repertoires of action conducive to the ' display of sovereign assertiveness for which the implementation of liberal ideas offers nothing more and nothing less than a conduit' $(2014,15)$. The claim that 'liberal values' are definitive of the nation can only be secured by seeking out a defining contrast with the inherent religiosity, assertive patriarchy, risky transnationalism and brittle loyalties held to characterise 'Muslim communities'.

It is for this reason that, while underling the importance of Cammaert's discussion of normalisation, I would disagree that this 'contemporary fascism has managed to transform that which was deemed to be unacceptable and politically repugnant only a short time ago into the new "common sense"'. While this extended example from the UK is highly particular, I would suggest that it is sufficiently heuristic to draw attention to a more dynamic set of relations around the reproduction of racialised 'common sense'. On the 
one hand, many contexts are characterised by what David Renton (2019) has theorised as 'convergence on the right', where traditionally conservative parties have forged formal and informal alliances and links with parties and actors far further to the right, and are increasingly prepared to parrot their rhetoric and openly adopt their 'anti-immigration' standpoints and policies (a lack of real surprise at Tories retweeting anonymous fascists is one minor consequence of this). And on the other, the far-right has not just opportunistically hijacked the 'value of values', but further radicalised an already existing exclusionary force.

To the question of media. Far-right Twitter accounts come and go, often generating significant traction without any obvious relation to organised movements. As a stage of his reinvention of self after the EDL, its leader Stephen Yaxley-Lennon ('Tommy Robinson') reinvented himself as a journalist, working for the Canadian far-right media company Rebel Media. Britain First was eventually banned from Facebook, but Facebook seethes with the mutation of far-right organisational forms, initiatives and a more diffuse circulation of digital bricolage. In linking 'neo-fascist discourse' to the techno-social infrastructures and economic models of interactive media platforms in a deeply integrated digital media ecology, Cammaerts makes a key and compelling argument about the productivity of what he has previously termed the 'mediation opportunity structure' to neo-fascist actors. It is also this emergent and productive affinity, I think, which prompts him to park the kinds of complex definitional discussions which frequently accompany the invocation of fascism. For, if fascism is often used far too loosely to be of analytical or political value, it is also the case, as he asserts, that the use of 'more sanitised denominations' - such as the equally over-stretched rubric of 'populism' - does little of service for critical or antiracist clarity, either.

In a recent essay, Enzo Traverso notes that 'fascism is a key part of our historical consciousness and our political imaginary' but that to grasp the 'heterogenous and composite' formation of the contemporary radical right, a notion of 'postfascism' is more apposite, as while it can encompass overtly neo-fascist forces that seek to regenerate aspects of interwar-fascisms, the prefix is forward-looking, denoting a 'phenomenon in transition, a movement that is still in transformation and has not yet crystallised' (2019, 5-6). Postfascism, therefore, 'belongs to a particular regime of historicity - the beginning of the twentyfirst century - which explains its erratic, unstable and often contradictory ideological content' $(2019,7)$. Systems of connective media are and will be fully germane to this transition. Without conceding to the mediacentrism that can so easily creep into accounts of media and political power, Cammaerts contributes to a growing body of work that demonstrates how the contemporary communications environment does more than provide extended space for far-right ideological activity (for overview see Titley 2019, 108-132). This attention to media dynamics and the circulation and distribution of discourse is critical to understanding the protean diversity that Traverso underlines.

To return to the article's central examples, Modi's BJP and its milieu hews very close to those definitional understandings of fascism which emphasise the centrality of a reactionary mass movement and its capacities for 'cleansing' violence. The BJP has a significant overlap with the paramilitary cadre organisation the Rashtriya Swayamsevak Sangh (RSS), founded in 1925 and keenly influenced by German and Italian fascisms. It has instigated and been involved in countless episodes of anti-Muslim violence, an activism, as Mohammad Ali (2020) examines in an astonishing investigative article in Wired, that has 
been dangerously enhanced by the integration of What's App into both local coordination and expansive networks of 'fake news' sharing. It is not to let the pro-Modi sycophancy of much mainstream Indian media off the hook to note the extreme danger posed by the intensive real-time circulation of anti-Muslim rumours, memes and disinformation through social media (Bajoria 2020).

Despite Trump's princely formation in the feudal ruling class of American capitalism, his election hinged on laying successful claim to the insurgent authenticity of the populist outsider, in no small part because of his willingness to dispense with the '..coded 'dog whistle' signals that conservatives had learned to employ when the spoke about race, ethnicity, crime and immigration' (Niewart 2017). As George Hawley (2017) has argued in his study of the so-called 'Alt Right', Trump's decisive intra-party victory over the 'traditional conservatism' of the Republican mainstream opened, in the early period of his presidency, a space of contingent affinity and attachment, with a wide variety of white nationalist, neo-Nazi and 'neo-Confederate' networks and groupuscules hailing the Trump era as their moment. The long-running fall-out of the fascist violence at the Unite the Right rally Charlottesville in 2017 eroded this space and split the primarily internet-enabled 'Alt-Right' (the Breitbart guru Steve Bannon also left the White House a week after the violence). Thus, Trump's 'fascism', unlike Modi's, does not have any relation to a mobilised base, and as Samuel Moyn (2020) has recently pointed out, Trump's vindictive and violent border politics was marshalled conventionally through those state agencies with 'long histories of killing, subjugation and terror'. Yet he retains important loyalties and affinities within what Yochai Benckler et al. (2017) characterise as a hyper-partisan, 'distinct and insulated media system' that is comprised of interlocking scales of activity and reach, from Fox News to the endless proliferation of small-scale, supportive social media personalities, initiatives and brands.

What these contexts make clear is that in a complex digital media ecology characterised by incessant and accelerated communication, dense transnational networking, and transformations in the distribution of media power, media infrastructures and processes are, inter alia, generative of a bewildering variety of far-right actors, political imaginaries, and political forms.Neo/Post-Fascist discourse is not tied to fascist actors, it is distributed in its production and circulation, a discursive seepage of talking points, memes, mythologies, manipulated statistics, astro-turfed sources, manipulated images and deep fake simulations that can slip into anyone's mentions. These forms prosecute endless provocation and disruption, generating, as Cammaerts points out, a now ubiquitous form of political noise that asks us to think very carefully, as to the mediatic and political conditions of viably pluralistic publics. I may not fully subscribe to the normative coordinates that the article proposes for this task, but I fully share its concentrated delineation of what is at stake.

\section{Note}

1. For further information, see this profile by Hope Not Hate: https://www.hopenothate.org.uk/ research/britain-first/

\section{Disclosure statement}

No potential conflict of interest was reported by the author(s). 


\section{Notes on contributor}

Gavan Titley is Senior Lecturer in the Department of Media Studies, Maynooth University, and a docent in the Swedish School of Social Science, University of Helsinki. He books include The Crises of Multiculturalism: Racism in a Neoliberal Age (with Alana Lentin, 2011), Racism and Media (2019) and Is Free Speech Racist? (2020).

\section{References}

Ali, Mohammad. 2020. The rise of a Hindu vigilante in the age of WhatsApp and Modi. Wired, April 14. Last accessed 18.5.20. https://www.wired.com/story/indias-frightening-descent-social-mediaterror/.

Andrejevic, Mark. 2013. Infoglut: How too much information is changing the way we think and know. London: Routledge.

Appadurai, Arjun. 2006. The fear of small numbers. Durham: Duke University Press.

Bajoria, Jayshree. 2020. CoronaJihad is only the latest manifestation: Islamophobia in India has been years in the making. Human Rights Watch, May 1. https://www.hrw.org/news/2020/05/01/ coronajihad-only-latest-manifestation-islamophobia-india-has-been-years-making.

Ball, James. 2017. How 550 facebook users spread Britain first content to hundreds of thousands of people. 18 January. Last accessed 7 May 2020. https://www.buzzfeed.com/jamesball/how-550facebook-users-spread-britain-firstcontent-to-hundr.

Benkler, Yochai, Faris, Robert, Roberts, Hal and Zuckerman, Ethan. 2017. Study: Breitbart-led rightwing media Ecosystem Altered Broader media Agenda, Columbia Journalism Review. [Online] 3 March. Accessed 25 November 2018. www.cjr.org/analysis/breitbart-media-trump-harvardstudy.php.

Brown, Wendy. 2018.'Neoliberalism's Frankenstein: Authoritarian freedom in twenty-first century "democracies". Critical Times 1, no. 1: 60-79.

Burnett, John. 2015. Anti-racism: totem and taboo - a review article. Race \& Class 57, no. 1: 78-87.

Camus, Jean-Yves, and Lebourg Nicolas. 2017. Far-right politics in Europe. Boston: Harvard University Press.

Dobbernak, Jan. 2014. Sovereignty, security and muscular liberalism: Debating "Sharia courts" in Britain. EUI Working Paper RSCAS 2014/103.

Gerbaudo, Paulo. 2020. Cornonavirus embarrassed Trump and Bolsanaro. But the global right will fight back. The Guardian. Last accessed 17 May 2020. https://www.theguardian.com/ commentisfree/2020/apr/01/populist-right-coronavirus.

Hawley, George. 2017. Making sense of the alt-right. New York: Columbia University Press.

Kelsey, Darren. 2017. Media and affective mythologies. Discourse, archetype and ideology in contemporary politics. Basingstoke: Palgrave macmillan.

Kundnani, Arun. 2014. Th e Muslims Are coming! Islamophobia, extremism and the domestic war on terror. London: Verso.

Lapierre, Nicole. 2020. Faut-il se ressembler pour s'assembler? Paris: Éditions du Seuil.

Mbembe, Achille. 2017. Critique of black reason. Durham: Duke University Press.

Mills, Charles W. 1997. The racial contract. New York: Cornell University Press.

Mirzoeff, Nicholas. 2020. Antifascist visual tactics. Last accessed 20 May 2020. http://www. nicholasmirzoeff.com/bio/antifascist-visual-tactics/?fbclid=IwAR19p9_a6VBcGyZ4KUc21 hspv6s7P dtFDyglkWcRtVmq4ngOwmeK9dRxTRI.

Moyn, Samuel. 2020. The trouble with comparisons. New York Review of Books. May 19.

Neiwert, David. 2017. Alt-America: The rise of the radical right in the Age of Trump. London: Verso.

Renton, David. 2019. The New authoritarians: Convergence on the right. London: Pluto Press.

Smith, Evan. 2020. No platform: A history of anti-fascism, Universities, and the Limits of free speech. London: Routledge.

Tell MAMA. 2014. Facebook report: Rotherham, hate and the far-right online. Last accessed 6 May 2020. https://www.tellmamauk.org/wp-content/uploads/2014/09/Rotherham.pdf.

Titley, Gavan. 2019. Racism and media. London: Sage Publications. 
Titley, Gavan. 2020. Is free speech racist? Cambridge: Polity.

Traverso, Enzo. 2019. The new faces of fascism. London: Verso.

Tufail, Waqas. 2015. 'Rotherham, Rochdale, and the racialised threat of the 'muslim grooming gang. International Journal for Crime, Justice and Social Democracy 4, no. 3: 30-43.

Valenta, Markha. 2017. Symbolic politics with brutally real effects: when "nobodies" make history. In After Charlie Hebdo: terror, racism and free speech, ed. G. Titley, D. Freedman, A. Mondon, and G. Khiabany, 129-145. London: Zed.

Valluvan, Sivamohan. 2019. The Clamour of nationalism. race and nation in twenty-first century Britain. Manchester: Manchester University Press.

Vanaik, Achin. 2019. Modi might finally have gone too far. Jacobin Magazine, December 22. Last accessed 17 May 2020. https://www.jacobinmag.com/2019/12/narendra-modi-india-citizenshipamendment-act-muslims-bjp.

Yasir, Sameer. 2020. India is scapegoating Muslims for the Spread of the Virus. Foreign Policy, April 22. Last accessed 18 May 2020. https://foreignpolicy.com/2020/04/22/india-muslims-coronavirusscapegoat-modi-hindu-nationalism/. 